\title{
Komórkowe mechanizmy zapewniające jakość żeńskich komórek rozrodczych ssaków
}

\section{STRESZCZENIE}

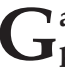
amety są skrajnie zróżnicowanymi komórkami, które uczestnicząc w zapłodnieniu dają początek nowemu organizmowi. Rolą w pełni funkcjonalnej gamety, oprócz umożliwienia zapłodnienia, jest także zapewnienie pełnego niezakłóconego rozwoju osobnika. Celem niniejszego artykułu jest przybliżenie funkcjonujących podczas oogenezy ssaków mechanizmów, które zapewniają właściwy przebieg procesów rozwojowych po zapłodnieniu oraz jakość przekazanego potomstwu materiału dziedzicznego.

\section{WPROWADZENIE}

We wczesnym zarodku ssaków (u myszy w siódmym dniu rozwoju) można wyróżnić grupę komórek ulokowanych u nasady omoczni. Są to pierwotne komórki płciowe (zwane też komórkami prapłciowymi), linia komórkowa, która $\mathrm{w}$ wyniku proliferacji i różnicowania rozwija się w komórki płciowe - gamety. Zarówno gamety żeńskie - oocyty, jak i gamety męskie - plemniki są krańcowo wyspecjalizowane, posiadając specyficzną morfologię, w tym szereg unikatowych struktur zapewniających prawidłowy przebieg zapłodnienia. Jednakże, myśląc o funkcjonalnej gamecie, nie należy zawężać problemu jedynie do kwestii mechaniki zapłodnienia. Obecnie wiadomo, że problem ograniczonych kompetencji gamety do uczestniczenia $\mathrm{w}$ zapłodnieniu można $\mathrm{w}$ wielu przypadkach rozwiązać poprzez zastosowanie procedur wspomaganego rozrodu. $\mathrm{W}$ tym przypadku wydaje się, że głównym problemem klinik wspomaganego rozrodu nie jest samo uzyskanie prawidłowo wyglądających zygot, lecz uzyskanie satysfakcjonującej wydajności ich rozwoju. Samo zapłodnienie bowiem nie jest jeszcze równoznaczne z prawidłowym rozwojem zarodka. Dlatego o jakości gamet na równi decyduje zarówno ich zdolność do prawidłowego uczestniczenia $\mathrm{w}$ zapłodnieniu, jak i ich zdolność do przeprowadzenia już uzyskanej zygoty przez pełen, niezakłócony proces rozwojowy. Innymi słowy, funkcjonalna gameta to taka, która zapewnia i zapłodnienie, i prawidłowy rozwój. Celem niniejszego artykułu będzie rozważenie jakości gamety żeńskiej w kontekście tych mechanizmów zachodzących podczas oogenezy, które zapewniają, że zapłodniony oocyt uzyskał pełne kompetencje rozwojowe.

\section{INFORMACJA MATCZYNA}

Oocyty są komórkami o dużych rozmiarach uzyskiwanych podczas tak zwanej fazy wzrostu. Na tym etapie oogenezy oocyty znajdują się już w jajniku zablokowane $\mathrm{w}$ profazie pierwszego cyklu mejotycznego (diploten profazy I). Faza wzrostu jest rozciągnięta w czasie (u myszy trwa około 17-18 dni) i charakteryzuje się wysoką aktywnością metaboliczną nakierowaną na produkowanie białek, cząsteczek RNA (transkryptów) oraz lipidów [1,2]. Szacuje się, że tempo syntezy białek wzrasta podczas fazy wzrostu czterdziestokrotnie [3] (przy czym oprócz białek gromadzonych w cytoplazmie oocytu znaczący udział ma tu także produkcja białek wchodzących w skład tak zwanej osłonki przejrzystej - struktury otaczającej oocyt o wielorakiej funkcji - od regulowania przestrzennej organizacji pęcherzyka jajnikowego, poprzez mechanizm zapłodnienia i na regulacji procesu implantacji skończywszy [3]. Osłonka przejrzysta nie jest jednak tematem tego artykułu a bliższe informacje na jej temat zainteresowany czytelnik może znaleźć w artykułach przeglądowych [3,4]). Całość metabolitów zgromadzonych w cytoplazmie oocytu podczas fazy wzrostu określamy jako informację matczyną i jest to kluczowa pula składników, która pokieruje rozwojem zarodka bezpośrednio po zapłodnieniu. Jakość tej informacji jest zatem składową jakości oocytu [5].

Znaczenie informacji matczynej jest bezpośrednio związane z pierwszą fazą rozwoju, który odbywa się przy wyłączonej transkrypcji [6]. Bezpośrednio po
Prof. dr hab. Zbigniew Polański $^{1 凶,}$

\section{Dr Łukasz Gąsior ${ }^{2}$}

${ }^{1}$ Pracownia Genetyki i Ewolucjonizmu, Instytut Zoologii i Badań Biomedycznych Uniwersytetu Jagiellońskiego, Kraków ${ }^{2}$ Zakład Neurobiologii, Instytut Farmakologii im. Jerzego Maja Polskiej Akademii Nauk, Kraków

https://doi.org/10.18388/pb.2021_421

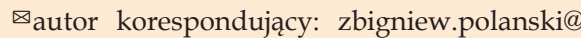
uj.edu.pl, gasior@if-pan.krakow.pl

Słowa kluczowe: jakość oocytu, informacja matczyna, segregacja chromosomów, uszkodzenia DNA, mitochondria, epigenetyczne reprogramowanie chromatyny

Wykaz skrótów: APC - kompleks promujący anafazę, ATM - kinaza ataxia telangiectasia mutated, ATR - kinaza ataxia telangiectasia and Rad3-related protein, DSB - dwuniciowe pęknięcia DNA, HR - naprawy przez homologiczną rekombinację, NHEJ - naprawy przez niehomologiczne łączenie wolnych końców, SAC - punkt kontrolny wrzeciona 


Gatunek
Człowiek
Mysz (Mus musculus)
Żaba (Xenopus levis)
Danio pręowane (Danio rerio)

zapłodnieniu transkrypcja, $\mathrm{z}$ wyjątkiem nielicznej frakcji genów, jest zablokowana i do czasu jej aktywacji rozwój odbywa się w oparciu o składniki zgromadzone w oocycie właśnie jako informacja matczyna [6]. U ssaków główna fala aktywacji genów zarodka zachodzi stosunkowo wcześnie - u myszy w stadium 2 komórek, u ludzi w stadium 4-8 komórek, a więc stosunkowo wcześnie w porównaniu np. do płazów, czy owadów (Tabela 1). Wydaje się, że jest to jeden z powodów, dla których rozmiary ssaczych oocytów są wyraźnie mniejsze niż rozmiary oocytów wielu innych taksonów, które ze względu na dłuższy czas rozwoju zachodzący przy zablokowanej transkrypcji wymagają zgromadzenia znacznie większej ilości informacji matczynej.

Znaczenie wielkości komórki jajowej u ssaków (a więc ilości zgromadzonej informacji matczynej) potwierdza także jej specyficzny, asymetryczny podział [7]. Zarówno podczas pierwszego, jak i podczas drugiego podziału mejotycznego wynikiem cytokinezy jest oocyt oraz ciałko kierunkowe. Asymetryczną cytokinezę umożliwia specyficzny mechanizm kontroli położenia wrzeciona komórkowego, które podczas pierwszego cyklu mejotycznego wędruje z pozycji centralnej pod powierzchnię oocytu [8]. Niewielkie rozmiary ciałek kierunkowych zapewniają, że informacja matczyna gromadzona przy olbrzymich nakładach energii podczas fazy wzrostu nie zostanie czterokrotnie zredukowana, co miałoby miejsce gdyby cytokineza obydwu podziałów mejotycznych zachodziła symetrycznie. Ciałka kierunkowe należy więc rozpatrywać jako minimalny pakunek, w którym oocyt może usunąć nadmiar materiału genetycznego, tak aby finalnie jego ilość wynosiła 1n1C.

\section{MECHANIZMY ZAPOBIEGAJĄCE ANEUPLOIDII}

Redukcja ilości materiału genetycznego do 1n1C podczas oogenezy wymaga precyzyjnego rozdziału chromosomów tak aby $\mathrm{w}$ następstwie podziałów mejotycznych każdy chromosom reprezentowany był tylko przez jedną chromatydę. Każda innej sytuacja, a więc obecność większej liczby chromatyd dowolnego chromosomu lub brak chromatydy dowolnego chromosomu skutkuje po zapłodnieniu przez plemnik aneuploidią zarodka - zwykle trisomią lub monosomią tego chromosomu, którego segregacja podczas mejozy była zaburzona. $W$ przeciwieństwie do aneuploidii komórek somatycznych, która najczęściej inicjuje mechanizmy eliminujące taką komórkę $\mathrm{w}$ procesie apoptozy, aneuploidia w komórkach zarodka skutkuje najczęściej jego poronieniem $[9,10]$ i tylko w nielicznych przypadkach urodzeniem potomka o nieprawidłowej liczbie chromosomów obarczonego określonymi anomaliami fenotypowymi. Jest powszechnie wiadome, że u ssaków ryzyko nieprawidłowego rozdziału chromosomów podczas mejozy oocytów wzrasta znacząco wraz z wiekiem samicy.
Szereg czynników odpowiada za prawidłowy rozdział materiału genetycznego podczas mejozy. Jednym z nich jest utrzymanie kohezji pomiędzy chromosomami homologicznymi (podczas pierwszego cyklu mejotycznego) oraz chromatydami siostrzanymi (podczas drugiego cyklu mejotycznego) do momentu kiedy aparat podziałowy jest skonfigurowany w sposób zapewniający ich rozdział do komórek potomnych. Oocyty ssaków rozpoczynają mejozę jeszcze w okresie płodowym i w tej też fazie rozwoju dochodzi do ustanowienia kohezji pomiędzy chromatydami i chromosomami homologicznymi [11]. Badania na myszach pokazały, że z upływem czasu kohezyny podlegają zużyciu, co prowadzi do przedwczesnego rozłączania się chromosomów homologicznych i chromatyd przez co niemożliwe staje się uzyskanie odpowiedniej konfiguracji we wrzecionie podziałowym, co generuje błędy segregacji [12-14]. Drugim znaczącym czynnikiem potęgującym ryzyko błędów segregacji chromosomów podczas mejozy ssaczych oocytów są anomalie w budowie wrzeciona podziałowego, które szczególnie często występują u starszych samic [15].

Szczególną cechą rozdziału materiału dziedzicznego podczas pierwszego podziału mejotycznego jest segregowanie do komórek potomnych całych chromosomów homologicznych. Aby zapobiec rozdzieleniu się $\mathrm{w}$ tej fazie mejozy pojedynczych chromatyd (co w większości przypadków skutkuje aneuploidią gamet) konieczne jest uzyskanie szczególnej orientacji biwalentów oraz ich prawidłowe podpięcie do mikrotubul wrzeciona. Krytycznym procesem jest tutaj złączenie się kinetochorów obu chromatyd chromosomu homologicznego, które w ten sposób tworzą pojedynczą jednostkę funkcjonalną, do której przyłączają się mikrotubule biegnące od biegunów wrzeciona [16]. Kolejnym warunkiem prawidłowej segregacji jest uzyskanie połączenia przez każdy z chromosomów homologicznych biwalentu do przeciwległego bieguna, co zapewni, że po degradacji kohezyn chromosomy homologiczne zostaną od siebie odciągnięte przez związane z mikrotubulami białka motoryczne [17]. Każda anomalia w połączeniu kinetochorów biwalentu z mikrotubulami wrzeciona odbiegająca od schematu zaprezentowanego powyżej niesie ogromne ryzyko nieprawidłowej segregacji chromosomów.

W przypadku oocytów złożoność procesów, które pozwolą spełnić powyższe wymogi, skutkuje znacznym wydłużeniem fazy M pierwszego cyklu mejotycznego, która w oocytach myszy trwa 6-10 godzin [18], a u większości ssaków nawet jeszcze dłużej. W istocie, badania z wykorzystaniem obrazowania dynamiki ruchów chromosomów podczas formowania wrzeciona podziałowego $\mathrm{w}$ pierwszej profazie mejotycznej oocytów myszy wykazały, że uzyskanie właściwej konfiguracji chromosomów jest rozciągniętym w czasie procesem zachodzącym na zasadzie „prób i błę- 
dów”, podczas którego połączenie między poszczególnymi biwalentami a mikrotubulami wrzeciona jest wielokrotnie nawiązywane, a następnie korygowane, zanim uzyskana zostanie prawidłowa konfiguracja [17].

Z powyższych rozważań wynika, że aby zapobiec aneuploidii, inicjacja anafazy nie powinna mieć miejsca przed właściwym podłączeniem chromosomów do mikrotubul wrzeciona. Rzeczywiście, taka synchronizacja istnieje, a istotą jej funkcjonowania jest wysyłanie do cytoplazmy przez niepodłączone (lub nieprawidłowo podłączone) kinetochory sygnału blokującego rozpoczęcie anafazy. Na poziomie molekularnym zapewnia to współdziałanie dwóch elementów: kompleksu promującego anafazę APC (APC, ang. Anaphase Promoting Complex) i punktu kontrolnego wrzeciona SAC (SAC, ang. Spindle Assembly Checkpoint). APC jest kompleksem białkowym, którego zadaniem jest inicjacja degradacji kohezyn - białek zapewniających zarówno przyleganie do siebie siostrzanych chromatyd, jak i (w przypadku pierwszego podziału mejotycznego) utrzymanie połączeń między chromosomami homologicznymi w biwalentach [19]. Kluczowym elementem łączącym aktywację APC z uzyskaniem prawidłowych połączeń między kinetochorami a mikrotubulami jest SAC [19]. Białka z rodziny Mad i Bub należące do ścieżki SAC wchodzą w interakcje z kinetochorami, ale tylko tymi, które jeszcze nie uzyskały połączenia z mikrotubulami. W wyniku tych interakcji dochodzi do zmian konformacji Bub i Mad, dzięki którym wiążą się z APC blokując jego aktywność. Uzyskiwanie prawidłowych podłączeń przez kolejne kinetochory podczas prometafazy powoduje spadek liczby wolnych kinetochorów. Tym samym dochodzi do spadku poziomu białek Mad i Bub o konformacji umożliwiającej wiązanie APC co skutkuje jego aktywacją, a w konsekwencji degradacją kohezyn i rozpoczęciem anafazy $[17,20]$.

Podczas gdy w mitozie współdziałanie wszystkich tych elementów znacząco obniża ryzyko nieprawidłowej segregacji, w przypadku dwóch kolejnych podziałów mejotycznych konieczne jest jeszcze odpowiednie stopniowanie degradacji kohezyn. Podczas pierwszej anafazy mejotycznej degradacji powinny ulegać jedynie te kohezyny, które utrzymują połączenie chromosomów homologicznych, gdyż rozłączenie chromatyd w tej fazie mejozy skutkowałoby aneuploidią. Rolę strażnika wypełnia specyficznie dla pierwszego podziału mejotycznego białko shugoshin (w języku japońskim strażnik) chroniące przed degradacją w tej fazie mejozy te kohezyny, które zapewniają przyleganie chromatyd siostrzanych [21].

W tej złożonej układance do roli elementu kontrolnego obniżającego ryzyko aneuploidii urasta SAC, gdyż to on "decyduje" kiedy system jest gotowy do prawidłowej segregacji chromosomów aktywując w stosownym momencie APC. Co ciekawe, ze względu na to, że u ssaków błędna segregacji chromosomów zachodzi z częstością kilkukrotnie wyższą w mejozie żeńskiej niż w męskiej [22], funkcjonowanie SAC w oocytach było przez pewien czas kwestionowane zanim ostatecznie udowodniono, że kontroluje on segregację chromosomów w oocytach ssaków zarówno podczas pierwszego, jak i drugiego podziału mejotycznego $[23,24]$.
Efektywność działania SAC u ssaków wydaje się jednak wyraźnie obniżona $\mathrm{w}$ oocytach $\mathrm{w}$ porównaniu $\mathrm{z}$ innymi rodzajami komórek. Jednym z powodów mogą być ich bardzo duże rozmiary. W przypadku komórek tak dużych jak oocyty, elementy ścieżek sygnałowych kontrolujących rozmaite procesy występują w większym "rozcieńczeniu” ze względu na dużą objętość cytoplazmy. Z tego powodu mogą działać mniej efektywnie niż w komórkach o mniejszych rozmiarach. Eksperymentalne zredukowanie objętości oocytu myszy rzeczywiście skutkowało zarówno mniejszą częstością defektów formowania wrzeciona podziałowego, jak i podniesieniem efektywności SAC [25]. Kolejną przyczyną obniżenia wydajności działania SAC w oocytach może być spadek ekspresji białek tej ścieżki zaobserwowany u starszych samic [26,27], co mogłoby prowadzić do postępującego wraz z wiekiem obniżenia efektywności SAC w oocytach.

Podsumowując, oocyty ssaków posiadają zatem mechanizmy zabezpieczające prawidłową segregację materiału dziedzicznego razem ze współdziałającym z nimi systemem kontroli jakości aparatu podziałowego (SAC). Jednocześnie specyfika tych komórek (np. duże rozmiary, długi okres upływający do wejścia w fazę podziałową) powoduje, że są narażone na stosunkowo wysokie ryzyko błędów segregacji, przy czym istotnym elementem tego ryzyka jest zaawansowany wiek samic.

\section{MECHANIZMY ODPOWIEDZIALNE ZA INTEGRALNOŚĆ MATERIAŁU GENETYCZNEGO OOCYTÓW}

Obecnie wyróżnia się cały szereg typów uszkodzeń DNA, od pęknięć nici DNA, poprzez modyfikacje zasad azotowych, aż do zaburzeń przestrzennej struktury helisy DNA. Spośród nich szczególnie niebezpieczną kategorię stanowią dwuniciowe pęknięcia DNA (DSBs, ang. Double Strand Breaks) ze względu na dewastujące szkody jakie powodują [28]. Przyczyny powstawania DSBs są wielorakie, a pośród nich na szczególne wyróżnienie zasługuje stres oksydacyjny i związany z nim podwyższony poziom reaktywnych form tlenu (RFT). Podniesiony ponad fizjologiczną normę poziom RFT w komórkach jest wyznacznikiem naszych czasów i wynika z najprzeróżniejszych czynników, głównie społecznych i środowiskowych, począwszy od stresu psychicznego [29], poprzez zanieczyszczenie środowiska [30], na nadmiernym stosowaniu substancji psychotropowych skończywszy [31].

RFT w przeważającej mierze powodują powstawanie uszkodzeń zasad azotowych lub powstawanie pojedynczych pęknięć DNA (SSBs, ang. Single Strand Breaks). SSBs same $\mathrm{w}$ sobie nie stanowią jeszcze dużego zagrożenia dla integralności genomu, ale w wyniku replikacji nici niosącej SSB, bądź też pojawienia się dużej liczby SSBs w bezpośrednim sąsiedztwie, może dojść do ich konwersji do bardziej niebezpiecznej formy pęknięcia obejmującej obie nici w podwójnej helisie, czyli DSB [32]. Ponieważ oocyty ssaków są zatrzymane w jajniku w profazie pierwszego podziału mejotycznego (trwającą u ludzi nawet ponad 40 lat), mogą w tym czasie gromadzić potencjalnie dużą liczbę uszkodzeń 
DNA. Brak odpowiednich systemów naprawczych doprowadziłby więc, w bardzo krótkim czasie, do całkowitej fragmentacji genomu oocytu. Należy także zwrócić uwagę na coraz powszechniej stosowane procedury wspomaganego rozrodu, w których oocyty, ze względu na bezpośrednie wystawienie na działanie środowiska zewnętrznego, są szczególnie narażone na stres oksydacyjny [31].

W przypadku pojawienia się DSBs i innych uszkodzeń DNA dochodzi do uruchomieniem szeregu mechanizmów ochrony integralności genomu, koordynowanych w ramach kompleksowej odpowiedzi komórki na powstałe uszkodzenia, określanej jako DDR (DDR, ang. DNA Damage Response). Do głównych procesów koordynowanych przez DDR należą: uruchomienie napraw DNA, aktywacja punktów kontrolnych blokujących cykl komórkowy oraz eliminowanie komórek z nienaprawionymi uszkodzeniami drogą apoptozy.

DSBs naprawiane są poprzez dwa alternatywne mechanizmy: homologiczną rekombinację (HR, ang. Homologous Recombination) lub niehomologiczne łączenie wolnych końców (NHEJ, ang. Non-Homologous End Joining) [33]. Angażują one szereg białek naprawczych, z których wiele kluczowych, jak BRCA1, Rad51, MERE11 lub ATM ulega obniżonej ekspresji w oocytach starszych samic, co może skutkować obniżeniem zdolności naprawczych oocytu. Istotnie, nowe dane wskazują na spadek efektywności napraw DNA wraz z wiekiem samic ssaków oraz związaną z tym akumulacją nienaprawionych defektów w genomie oocytów, co prowadzi do utraty rezerwy jajnikowej i przedwczesnej menopauzy albo do punktowych mutacji $\mathrm{i}$ aneuploidii $\mathrm{w}$ genomie potomstwa takich matek [34,35]. Jednocześnie następuje wzrost tolerancji na uszkodzenia i obniżenie zdolności oocytów do apoptozy w odpowiedzi na zgromadzone uszkodzenia $[34,35]$.

Regulacja cyklu komórkowego podczas mejozy oocytów różni się znacznie od regulacji w komórkach mitotycznych $[20,36]$. Jednak, pomimo tych różnic, punkty kontrolne cyklu komórkowego, które blokują proliferację w komórkach zagrożonych utratą funkcji i integralności genomowej, również w oocytach występują. Pierwszy punkt kontrolny kontroluje wznowienie mejozy, która zablokowana została w profazie pierwszej jeszcze $\mathrm{w}$ jajniku płodowym [37]. Mimo że ten punkt kontrolny działa już w oocytach profazowych (a nie pomiędzy fazą G2 i M), to uznaje się, iż jest on odpowiednikiem punktu kontrolnego regulującego wyjście komórek z fazy G2 cyklu komórkowego do fazy M (punkt G2/M) w komórkach mitotycznych [38]. W odniesieniu do uszkodzeń genomu punkt G2/M jest głównym mechanizmem zabezpieczającym przed wejściem $\mathrm{w}$ fazę podziałową komórek z uszkodzonym DNA [39].

Mimo podobnej funkcji do swojego mitotycznego odpowiednika, profazowy punkt kontrolny G2/M w oocytach wykazuje nieznaczne różnice $\mathrm{w}$ mechanizmie działania. $\mathrm{W}$ mitozie, przejście G2/M jest kontrolowane przez dwa szlaki fosforylacji, w których kinazy ATR (ATR, ang. Ataxia Telangiectasia and Rad3-related protein) i ATM (ATM, ang. Ataxia Telangiectasia Mutated) w odpowiedzi na szerokie spektrum defektów DNA fosforylują, odpowiednio, kinazy Chk1 i
Chk2 $[37,40]$. Te, z kolei, przekazują sygnał o występowaniu defektów genomu poprzez fosforylację białek z rodziny fosfataz Cdc25 - głównie fosfatazy Cdc25C. Prowadzi to do zahamowania aktywności fosfatazy Cdc25C, która nie jest teraz $\mathrm{w}$ stanie zdefosforylować kluczowego dla wejścia $\mathrm{W}$ fazę M kompleksu Cdk1/cyklina B, co powstrzymuje postęp cyklu komórkowego [41]. W profazowym punkcie G2/M oocytu, w odpowiedzi na uszkodzenia DNA, dochodzi do fosforylacji tylko Cdc25B [42], zaś sama aktywacja punktu odbywa się przez ATM/Chk1, a nie ATM/Chk2, jak to się dzieje w mitozie [38,43]. Chociaż rola kinazy Chk2 w sygnalizacji uszkodzeń DNA w oocycie również została wykazana $[38,43]$ ' to dokładny mechanizm jej aktywacji pozostaje nieznany. W porównaniu do komórek mitotycznych kolejną różnicą $\mathrm{w}$ funkcjonowaniu punktu kontrolnego G2/M w oocytach jest brak zaangażowania kinazy ATR $[44,45]$.

Co ciekawe, wyniki uzyskane na oocytach z nokautem genu p53-/- sugerują, że kodowane przez niego białko, zwane strażnikiem genomu, nie jest istotnym elementem odpowiedzi na uszkodzenia DNA w żeńskiej linii płciowej [46]. Rolę tę pełnią inne białka rodziny p53 kierujące komórki z nadmierną ilością uszkodzeń na drogę apoptozy, wśród których najważniejszym strażnikiem genomu oocytu wydaje się być p63 (TAp63, ang. Trans-Activating, p63) [46-48]. Wykazano, że TAp63 jest niezbędnym czynnikiem transkrypcyjnym aktywującym ekspresję białek proapoptotycznych w oocytach [48]. Ekspresja TAp63 ulega jednak dramatycznemu spadkowi, gdy oocyt wchodzi $w$ fazę wzrostu, dlatego mechanizm apoptozy w późnym etapie rozwoju oocytu przestaje zależeć od TAp63 i pozostaje na razie nieznany $[47,49]$.

Wejście $\mathrm{w}$ fazę $\mathrm{M}$ pociąga za sobą rozpoczęcie kondensacji chromosomów i tworzenie wrzeciona podziałowego. Jest to jednocześnie faza, w której funkcjonuje kolejny punkt kontrolny cyklu komórkowego - znany nam już SAC. Kanonicznie, jak już opisano powyżej, roli SAC przypisywano nadzór nad właściwym formowaniem się wrzeciona podziałowego poprzez monitorowanie interakcji między mikrotubulami a kinetochorami. Badania ostatnich lat wykazały, jednakże, że kluczowe białka składowe tego punktu kontrolnego, Mad i Bub, są zaangażowane w blokowanie oocytu w metafazie I także w obecności pęknięć DNA $[50,51]$. W tym przypadku aktywacja SAC nie wydaje się występować w miejscach uszkodzenia DNA, lecz bezpośrednio na kinetochorze, a więc często w dużej odległości od powstałego uszkodzenia [50,52]. Biorąc pod uwagę, że komórki somatyczne nie posiadają mechanizmów wykrywania defektów DNA w fazie M cyklu komórkowego [53-56], zdolność SAC do wykrywania uszkodzeń DNA w oocytach zaskakuje. Choć odpowiedzialny za nią mechanizm pozostaje mało poznany, wiadomo, że nie angażuje on kinaz ATM i ATR, które zwykle są integralnymi elementami sygnalizacji uszkodzeń genomu [57]. Przedstawione powyżej dowody na zaskakujący udział SAC w sygnalizacji uszkodzeń DNA w oocytach uzyskano w badaniach na myszach. Ostatnie doniesienie wskazujące, że oocyty ludzkie nie posiadają zdolności odpowiedzi na uszkodzenia DNA [58], z pewnością nie ułatwiają zrozumienia tego procesu. 


\section{ZNACZENIE MITOCHONDRIÓW}

Podziały mejotyczne oocytu, podobnie jak pierwsze podziały mitotyczne zarodka, $\mathrm{w}$ istotny sposób zależą od statusu energetycznego dzielących się komórek oraz kondycji samych mitochondriów [59]. Nie jest więc zaskoczeniem, że oocyty o wyższym poziomie ATP charakteryzują się wyższymi zdolnościami do zapłodnienia i lepszymi kompetencjami rozwojowymi $[60,61]$. Jądrowy czynnik oddechowy 1 (NRF1, ang. Nuclear Respiratory Factor1), oraz mitochondrialny czynnik transkrypcyjny (TFAM, ang. Mitochondrial Transcription Factor A) regulują wspólnie biogenezę mitochondriów [62], która jest prowadzona przez specyficzną dla mtDNA polimerazę Polg (polimeraza- $\gamma$ ) [63]. Oocyty o niskiej ekspresji TFAM i NRF1 posiadają niskie kompetencje rozwojowe [64]. Ekspresja polimerazy Polg oraz Tfam rośnie podczas wzrostu oocytu i w tym samym okresie gwałtownie rośnie liczba mitochondriów, potencjał ich błony mitochondrialnej, a także produkcja ATP $[61,65,66]$. Wiele badań wskazuje, że większa liczba mitochondriów oznacza lepsze kompetencje rozwojowe, a oocyty, które ulegają zapłodnieniu, posiadają znacznie większą liczbę mitochondriów, niż oocyty niezapłodnione $[60,67]$. W oocytach, które ukończyły fazę wzrostu, liczba kopii mt DNA nierzadko przekracza $200000 \mathrm{u}$ myszy, czy nawet $700000 \mathrm{u}$ ludzi. [68,69]. Wydaje się, że od tego momentu liczba kopii mtDNA w oocycie nie rośnie [70]. Tak więc uważa się, że zakończeniu fazy wzrostu oocytu towarzyszy zatrzymanie replikacji mtDNA, a ponowna replikacja zostaje uruchomiona dopiero po implantacji, kiedy zarodek zaczyna rosnąć [69].

Oprócz ilości mitochondriów niezwykle istotne znaczenie ma ich jakość, gdyż wszelkie zaburzenia stanu mitochondriów w oocycie mogą nie tylko poważnie ograniczać płodność, lecz także skutkować chorobami metabolicznymi, neurodegeneracyjnymi, i nowotworzeniem $\mathrm{w}$ rozwoju postnatalnym [59]. Wiadomo, że większość mutacji gromadzi się w komórkach wprost proporcjonalnie do wieku [71]. Stwierdzono, że wraz z wiekiem kobiet rośnie poziom stresu oksydacyjnego w oocytach, co powoduje wzrost liczby uszkodzeń oraz mutacji w mitochondrialnym DNA [72,73], które są przyczyną wielu ludzkich chorób. $\mathrm{Z}$ reguły choroby mitochondrialne obejmują zaburzenia neurologiczne, miopatie, cukrzycę i wiele endokrynopatii [74] i szacuje się, że jedna osoba na 5000 [75] dotknięta jest jedną z 270 mutacji skutkujących chorobą mitochondrialną [76]. Choroby o takim podłożu zwykle są wielonarządowe, a ich leczenie opiera się, niestety, głównie na łagodzeniu objawów [77]. Ponieważ cały genom mitochondrialny jest przekazywany potomstwu przez oocyt, z tej perspektywy staje się jasnym, jak istotne znaczenie ma przekazanie go w możliwie nienaruszonym stanie.

Badania mysich oocytów przyniosły odkrycie niezwykle interesującego mechanizmu, który poprzez zaangażowanie białek motorycznych, kinezyn i dynein, ogranicza ilość mitochondriów trafiających do ciałka kierunkowego podczas pierwszego podziału mejotycznego [78]. Pozwala to zachować wysoką liczbę mitochondriów w oocycie, co jak już opisano powyżej, wydaje się być dobrym prognostykiem jakości oocytu. W tym kontekście zaskakującym jest fakt, iż u myszy krytyczny próg, niezbędny dla właściwego rozwoju

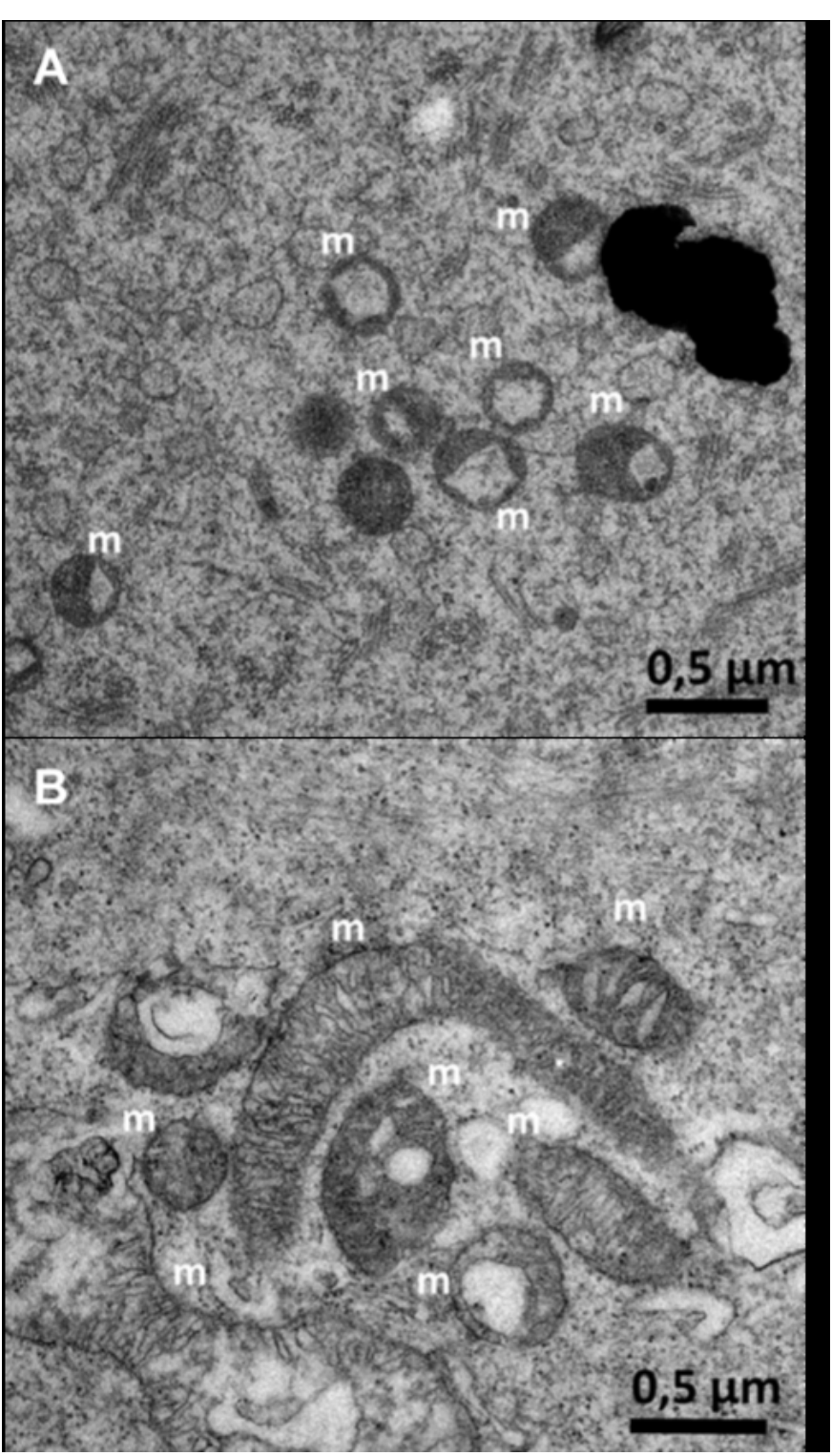

Rycina 1. Zgrupowanie mitochondriów zobrazowane z wykorzystaniem transmisyjnego mikroskopu elektronowego A - w mysim oocycie i B - w trofoblaście mysiej blastocysty. Literą "m" oznaczono pojedyncze mitochondria. (Zdjęcia Ł. Gąsior).

postimplantacyjnego, został określony na 40 000-50 000 kopii mtDNA [79]. Oznacza to, że liczba kopii mtDNA zawarta $\mathrm{w}$ typowym oocycie kilkukrotnie przekracza progowe wartości konieczne dla rozwoju! Nasuwa się zatem pytanie: dlaczego w oocycie funkcjonuje tak wiele mitochondriów? Morfologia mitochondriów w oocytach różni się znacząco od tej obserwowanej w komórkach somatycznych - w porównaniu z nimi zachowują one swój pierwotny i niezróżnicowany charakter, co przejawia się w kulistym kształcie, niewielkiej liczbie grzebieni mitochondrialnych, dużej gęstości matrix mitochondrialnej i mniejszej konsumpcji tlenu [80,81] (Ryc. 1A). Mitochondria oocytów pozostają transkrypcyjnie i bioenergetycznie wyciszone, a stan takiego funkcjonowania wydaje się ewolucyjnie konserwatywny [82-84]. Można sądzić, że tak duża liczba mitochondriów umożliwia pokrycie zapotrzebowania oocytu na energię przy jednoczesnym zachowaniu stosunkowo niskiej aktywności każdego z nich [83]. Obniża to poziom reaktywnych 
form tlenu, których produkcja jest nierozerwalnie związana z aktywnością mitochondrialną [85], redukując ryzyko powstawania mutacji i tym samym zapewniając odziedziczalność nienaruszonej matrycy mitochondrialnego DNA [86].

W czasie rozwoju przedimplantacyjnego dochodzi do przywrócenia aktywności mitochondriów i przybrania bardziej zróżnicowanego charakteru typowego dla komórek somatycznych [87]. Przykład pokazujący skalę zmian morfologicznych, jakie dokonują się w mitochondriach przedstawiono na fotografii 1, gdzie zestawiono uzyskany z mikroskopu elektronowego obraz mysiego oocytu i blastocysty.

\section{EPIGENETYCZNE REPROGRAMOWANIE CHROMATYNY W TOKU OOGENEZY}

Zapłodniona komórka jajowa, zygota, powinna posiadać pełen potencjał rozwojowy, czyli zdolność do stopniowego, skoordynowanego w czasie i przestrzeni, różnicowania się w komórki wszystkich tkanek przyszłego osobnika, jak i w tkanki pozazarodkowe, kreowane przejściowo tylko na czas rozwoju i niezbędne do jego podtrzymania. Osiąganie potencjału rozwojowego zachodzi stopniowo w trakcie gametogenezy i obecnie panuje powszechny pogląd, że jego istota są epigenetyczne modyfikacje chromatyny [88]. Składają się na nie metylacja DNA, potranslacyjne modyfikacje histonów (np. metylacja, acetylacja, fosforylacja), czy też zastępowanie kanonicznych form histonów przez ich niekanoniczne odpowiedniki [89]. Wszystkie te zmiany moga zachodzić w skali globalnej, czyli generalnie dotyczyć całej chromatyny, oraz w skali lokalnej, czyli ograniczać się na przykład do sekwencji konkretnych promotorów. Tak nałożone podczas gametogenezy znaczniki epigenetyczne będą później, podczas rozwoju, odpowiednio interpretowane przez mechanizmy odczytujące informację epigenetyczną skutkując aktywacją/wyciszeniem transkrypcji określonych genów odpowiedzialnych za konkretne procesy rozwojowe [88].

Ulokowanie prawidłowej informacji epigenetycznej $\mathrm{w}$ chromatynie komórek linii płciowej wymaga najpierw wymazania informacji epigenetycznej wprowadzonej do zygoty przez gamety. Metylacja DNA usuwana jest w dwóch falach, z których pierwsza zachodzi podczas migracji komórek prapłciowych do zawiązków gamet i odbywa się głównie na drodze demetylacji pasywnej $[90,91]$, czyli przez zablokowanie procesu odtwarzania metylacji DNA w kolejnych generacjach dzielących się komórek. Normalnie w każdym cyklu komórkowym po replikacji genomu nowopowstała nić DNA ulega metylacji w taki sposób, że odtworzony zostaje wzorzec metylacji, występujący w nici matrycowej co zapewnia, że komórki potomne odziedziczą wzór metylacji DNA występujący w komórce matczynej. Wyłączenie tego mechanizmu podczas pierwszej fali demetylacji powoduje zatem, że w aktywnie proliferujących komórkach linii płciowej poziom metylacji znacząco się obniża.

Druga fala demetylacji zachodzi wraz z zasiedlaniem przez komórki płciowe gonad płodowych [90]. W przeciwieństwie do pierwszej fali dominującym mechanizmem jest tutaj aktywna demetylacja, czyli zastępowanie zmety- lowanych cytozyn przez niezmetylowane. W dużej mierze obejmuje ona sekwencje, które podczas pierwszej fali podlegały ochronie, między innymi geny podlegające rodzicielskiemu piętnowaniu genomowemu [90]. Uważa się, że w tej fazie rozwoju komórki linii płciowej uzyskują najniższy poziom metylacji w cyklu życiowym osobnika [90].

Nowy, niezbędny dla uzyskania pełnego potencjału rozwojowego, wzór metylacji DNA nakładany jest według wzoru specyficznego dla płci. Wydaje się, że w komórkach linii żeńskiej (gdyż to one są przedmiotem tego artykułu) proces ten rozpoczyna się wraz z podjęciem przez oocyty fazy wzrostu [92]. Metylacja DNA zwiększa się stopniowo przez cały okres wzrastania oocytu i obejmuje zarówno geny podlegające, jak i niepodlegające rodzicielskiemu piętnowaniu genomowemu $[93,94]$.

Dopełnieniem reprogramowania chromatyny oocytu w fazie wzrostu są modyfikacje białek histonowych, które, podobnie jak metylacja DNA, mogą regulować ekspresję genów $[89,95]$. Lista opisanych modyfikacji histonów zachodzących w tej fazie rozwoju oocytów jest już niezwykle długa i obejmuje zarówno modyfikacje potranslacyjne określonych aminokwasów w ogonach histonowych $[96,97]$, jak i lokalne zastępowanie kanonicznych form histonów przez ich niekanoniczne odpowiedniki takie jak np. histon H3.3 [96]. Istnieją dane, które wskazują, iż przynajmniej cześć z tych modyfikacji, jakim lokalnie podlegają histony, podczas fazy wzrostu jest konieczna, aby w tych regionach chromatyny mogło dojść do nałożenia metylacji DNA [98]. Wydaje się, że jako całość, uwzględniając zarówno zmiany metylacji DNA, jak i modyfikacje histonów, proces reprogramowania przebiega z różną dynamiką w indywidualnych, rosnących oocytach. Doświadczenia, w których analizowano rozwój zarodków uzyskanych po transplantacji jąder rosnących oocytów do wyjądrzonych komórek jajowych, wskazują, że u myszy chromatyna niektórych oocytów osiąga pełen potencjał rozwojowy jeszcze przed zakończeniem wzrostu [99].

Końcowy etap fazy wzrostu charakteryzuje się stopniowym wyciszeniem transkrypcji, aż do jej wygaszenia w oocytach, które osiągnęły pełne rozmiary [100]. Jakjuż wspomniano $\mathrm{w}$ pierwszym rozdziale, wyciszenie transkrypcji $\mathrm{w}$ końcowej fazie gametogenezy i jej ponowne uruchomienie we wczesnym zarodku jest cechą charakterystyczną rozwoju zwierząt. Także temu procesowi towarzyszą modyfikacje histonów oraz gruntowne przemodelowanie konformacji chromatyny, która przyjmuje bardziej skondensowaną postać [101]. Uważa się, że podłożem zarówno wygaszenia transkrypcji, jak i zmian konformacyjnych chromatyny są zjawiska epigenetyczne [101]. Za epigenetycznym charakterem wyciszenia transkrypcji w oocytach ssaków przemawia między innymi to, że ponowne odblokowanie transkrypcji podczas aktywacji genomu zarodkowego zachodzi wraz z głębokimi potranslacyjnymi modyfikacjami histonów $[102,103]$.

\section{PIŚMIENNICTWO}

1. Pirino G, Wesco MP, Donovan PJ (2009) Protein kinase A regulates resumption of meiosis by phosphorylation of Cdc $25 \mathrm{~B}$ in mammalian oocytes. Cell Cycle 8: 665-670 
2. Wang JJ, Ge W, Liu JC, Klinger FG, Dyce PW, De Felici M, Shen W (2017) Complete in vitro oogenesis: Retrospects and prospects. Cell Death Differ 24: 1845-1852

3. Wassarman PM (2008) Zona pellucida glycoproteins. J Biol Chem 283: 24285-24289

4. Moros-Nicolás C, Chevret $\mathrm{P}$, Jiménez-Movilla M, Algarra B, Cots-Rodríguez P, González-Brusi L, Avilés M, Izquierdo-Rico MJ (2021) New Insights into the Mammalian Egg Zona Pellucida. Int J Mol Sci 22: 3276

5. Zhang K, Smith GW (2015) Maternal control of early embryogenesis in mammals. Reprod Fertil Dev 27: 880-896

6. Schulz KN, Harrison MM (2019) Mechanisms regulating zygotic genome activation. Nat Rev Genet 20: 221-234

7. Reader KL, Stanton JAL, Juengel JL (2017) The role of oocyte organelles in determining developmental competence. Biology (Basel) 6:

8. Sun S-C, Kim N-H (2013) Molecular Mechanisms of Asymmetric Division in Oocytes. Microsc Microanal 19: 883-897

9. Macklon NS, Geraedts JPM, Fauser BCJM (2002) Conception to ongoing pregnancy: The "black box" of early pregnancy loss. Hum Reprod Update 8: 333-343

10. Rubio C, Rodrigo L, Mercader A, Mateu E, Buendía P, Pehlivan T, Viloria T, De Los Santos MJ, Simón C, Remohí J, Pellicer A (2007) Impact of chromosomal abnormalities on preimplantation embryo development. Prenat Diagn 27: 748-756

11. Burkhardt S, Borsos M, Szydlowska A, Godwin J, Williams SA, Cohen PE, Hirota T, Saitou M, Tachibana-Konwalski K (2016) Chromosome Cohesion Established by Rec8-Cohesin in Fetal Oocytes is Maintained without Detectable Turnover in Oocytes Arrested for Months in Mice. Curr Biol 26: 678-685

12. Lister LM, Kouznetsova A, Hyslop LA, Kalleas D, Pace SL, Barel JC, Nathan A, Floros V, Adelfalk C, Watanabe Y, Jessberger R, Kirkwood TB, Höög C, Herbert M (2010) Age-related meiotic segregation errors in mammalian oocytes are preceded by depletion of cohesin and Sgo2. Curr Biol 20: 1511-1521

13. Murdoch B, Owen N, Stevense M, Smith H, Nagaoka S, Hassold T, McKay M, Xu H, Fu J, Revenkova E, Jessberger R, Hunt P (2013) Altered Cohesin Gene Dosage Affects Mammalian Meiotic Chromosome Structure and Behavior. PLoS Genet 9: e1003241

14. Sakakibara Y, Hashimoto S, Nakaoka Y, Kouznetsova A, Höög C, Kitajima TS (2015) Bivalent separation into univalents precedes age-related meiosis i errors in oocytes. Nat Commun 6:1-8

15. Lodge C, Herbert M (2020) Oocyte aneuploidy-more tools to tackle an old problem. Proc Natl Acad Sci U S A 117: 11850-11852

16. Rabitsch KP, Petronczki M, Javerzat JP, Genier S, Chwalla B, Schleiffer A, Tanaka TU, Nasmyth K (2003) Kinetochore recruitment of two nucleolar proteins is required for homolog segregation in meiosis I. Dev Cell 4: 535-548

17. Kitajima TS (2018) Mechanisms of kinetochore-microtubule attachment errors in mammalian oocytes. Dev Growth Differ 60: 33-43

18. Polański Z (1997) Genetic background of the differences in timing of meiotic maturation in mouse oocytes: A study using recombinant inbred strains. J Reprod Fertil 109: 109-114

19. Marston AL, Wassmann K (2017) Multiple duties for spindle assembly checkpoint kinases in meiosis. Front Cell Dev Biol 5: 109

20. Polanski Z (2013) Spindle assembly checkpoint regulation of chromosome segregation in mammalian oocytes. Reprod Fertil Dev 25: 472-83

21. Kitajima TS, Kawashima SA, Watanabe Y (2004) The conserved kinetochore protein shugoshin protects centromeric cohesion during meiosis. Nature 427: 510-517

22. Nagaoka SI, Hassold TJ, Hunt PA (2012) Human aneuploidy: Mechanisms and new insights into an age-old problem. Nat Rev Genet 13: 493-504

23. Tsurumi C, Hoffmann S, Geley S, Graeser R, Polanski Z (2004) The spindle assembly checkpoint is not essential for CSF arrest of mouse oocytes. J Cell Biol 167: 1037-50

24. Homer HA, McDougall A, Levasseur M, Murdoch AP, Herbert M (2005) Mad2 is required for inhibiting securin and cyclin B degrada- tion following spindle depolymerisation in meiosis I mouse oocytes. Reproduction 130: 829-43

25. Kyogoku H, Kitajima TS (2017) Large Cytoplasm Is Linked to the Error-Prone Nature of Oocytes. Dev Cell 41: 287-298.e4

26. Craven L, Elson JL, Irving L, Tuppen HA, Lister LM, Greggains GD, Byerley S, Murdoch AP, Herbert M, Turnbull D (2011) Mitochondrial DNA disease: new options for prevention. Hum Mol Genet 20: R16874

27. Steuerwald N, Cohen J, Herrera RJ, Sandalinas M (2001) Association between spindle assembly checkpoint expression and maternal age in human oocytes. Mol Hum Reprod 7: 49-55

28. Nickoloff JA, Sharma N, Taylor L (2020) Clustered DNA double-strand breaks: Biological effects and relevance to cancer radiotherapy. Genes (Basel) 11: 99

29. Prasad S, Tiwari M, Pandey AN, Shrivastav TG, Chaube SK (2016) Impact of stress on oocyte quality and reproductive outcome. J Biomed Sci 23:

30. Susiarjo M, Hassold TJ, Freeman E, Hunt PA (2007) Bisphenol A exposure in utero disrupts early oogenesis in the mouse. PLoS Genet 3: e5

31. Agarwal A, Aponte-Mellado A, Premkumar BJ, Shaman A, Gupta S (2012) The effects of oxidative stress on female reproduction: A review. Reprod Biol Endocrinol 10: 49

32. Lindahl T (1993) Instability and decay of the primary structure of DNA. Nature 362: 709-715

33. Brandsma I, Gent DC (2012) Pathway choice in DNA double strand break repair: observations of a balancing act. Genome Integr 3: 9

34. Govindaraj V, Keralapura Basavaraju R, Rao AJ (2015) Changes in the expression of DNA double strand break repair genes in primordial follicles from immature and aged rats. Reprod Biomed Online 30 303-310

35. Titus S, Li F, Stobezki R, Akula K, Unsal E, Jeong K, Dickler M, Robson M, Moy F, Goswami S, Oktay K (2013) Impairment of BRCA1-related DNA double-strand break repair leads to ovarian aging in mice and humans. Sci Transl Med 5: 172ra21

36. Kubiak JZ, Ciemerych MA, Hupalowska A, Sikora-Polaczek M, Polanski Z (2008) On the transition from the meiotic to mitotic cell cycle during early mouse development. Int J Dev Biol 52: 201-217

37. Reinhardt HC, Yaffe MB (2009) Kinases that control the cell cycle in response to DNA damage: Chk1, Chk2, and MK2. Curr Opin Cell Biol 21: $245-55$

38. Bolcun-Filas E, Rinaldi VD, White ME, Schimenti JC (2014) Reversal of female infertility by Chk2 ablation reveals the oocyte DNA damage checkpoint pathway. Science 343: 533-6

39. Stark GR, Taylor WR (2004) Analyzing the G2/M checkpoint. Methods Mol Biol 280: 51-82

40. Mu XF, Jin XL, Farnham MMJ, Li Y, O'Neill C (2011) DNA Damage-Sensing Kinases Mediate the Mouse 2-Cell Embryo's Response to Genotoxic Stress. Biol Reprod 85: 524-535

41. Donzelli M, Draetta GF (2003) Regulating mammalian checkpoints through Cdc25 inactivation. EMBO Rep 4: 671-7

42. Marangos P, Carroll J (2012) Oocytes progress beyond prophase in the presence of DNA damage. Curr Biol 22: 989-94

43. Dai X-X, Duan X, Liu H-L, Cui X-S, Kim N-H, Sun S-C (2014) Chk2 regulates cell cycle progression during mouse oocyte maturation and early embryo development. Mol Cells 37: 126-32

44. Ho GPH, Margossian S, Taniguchi T, D'Andrea AD (2006) Phosphorylation of FANCD2 on two novel sites is required for mitomycin $C$ resistance. Mol Cell Biol 26: 7005-15

45. Pacheco S, Garcia-Caldés M, Roig I (2018) ATR function is indispensable to allow proper mammalian follicle development. BioRxiv 128 489-500

46. Suh E-K, Yang A, Kettenbach A, Bamberger C, Michaelis AH, Zhu Z, Elvin JA, Bronson RT, Crum CP, McKeon F (2006) p63 protects the female germ line during meiotic arrest. Nature 444: 624-8 
47. Livera G, Petre-Lazar B, Guerquin M-J, Trautmann E, Coffigny H, Habert R (2008) P63 Null Mutation Protects Mouse Oocytes From Radio-Induced Apoptosis. Reproduction 135: 3-12

48. Kerr JB, Hutt KJ, Michalak EM, Cook M, Vandenberg CJ, Liew SH, Bouillet P, Mills A, Scott CL, Findlay JK, Strasser A (2012) DNA Damage-Induced Primordial Follicle Oocyte Apoptosis and Loss of Fertility Require TAp63-Mediated Induction of Puma and Noxa. Mol Cell 48: 343-352

49. Carroll J, Marangos P (2013) The DNA damage response in mammalian oocytes. Front Genet 4: 117

50. Collins JK, Lane SIR, Merriman JA, Jones KT (2015) DNA damage induces a meiotic arrest in mouse oocytes mediated by the spindle assembly checkpoint. Nat Commun 6: 8553

51. Marangos P, Stevense M, Niaka K, Lagoudaki M, Nabti I, Jessberger R, Carroll J (2015) DNA damage-induced metaphase I arrest is mediated by the spindle assembly checkpoint and maternal age. Nat Commun 6: 8706

52. Dumollard R, Marangos P, Fitzharris G, Swann K, Duchen M, Carroll $\mathrm{J}$ (2004) Sperm-triggered Ca2+ oscillations and Ca2+ homeostasis in the mouse egg have an absolute requirement for mitochondrial ATP production. Development 131: 3057-67

53. Bakhoum SF, Kabeche L, Murnane JP, Zaki BI, Compton DA (2014) DNA-damage response during mitosis induces whole-chromosome missegregation. Cancer Discov 4: 1281-1289

54. Cesare AJ (2014) Mitosis, double strand break repair, and telomeres: A view from the end. BioEssays 36: 1054-1061

55. Orthwein A, Fradet-Turcotte A, Noordermeer SM, Canny MD, Brun CM, Strecker J, Escribano-Diaz C, Durocher D (2014) Mitosis inhibits DNA double-strand break repair to guard against telomere fusions. Science 344: 189-193

56. Terasawa M, Shinohara A, Shinohara M (2014) Canonical Non-Homologous End Joining in Mitosis Induces Genome Instability and Is Suppressed by M-phase-Specific Phosphorylation of XRCC4. PLoS Genet 10: e1004563

57. Maréchal A, Zou L (2013) DNA Damage Sensing by the ATM and ATR Kinases. Cold Spring Harb Perspect Biol 5: a012716

58. Rémillard-Labrosse G, Dean NL, Allais A, Mihajlović AI, Jin SG, Son WY, Chung JT, Pansera M, Henderson S, Mahfoudh A, Steiner N, Agapitou K, Marangos P, Buckett W, Ligeti-Ruiter J, FitzHarris G (2020) Human oocytes harboring damaged DNA can complete meiosis I. Fertil Steril 113: 1080-1089

59. Gąsior Ł, Daszkiewicz R, Ogórek M, Polański Z (2017) Mitochondrial functionality in female reproduction. Postepy Hig Med Dosw 71: 690 702

60.Stojkovic M, Machado SA, Stojkovic P, Zakhartchenko V, Hutzler P Gonçalves PB, Wolf E (2001) Mitochondrial distribution and adenosine triphosphate content of bovine oocytes before and after in vitro maturation: correlation with morphological criteria and developmental capacity after in vitro fertilization and culture. Biol Reprod 64: 904-9

61. Nagano M, Katagiri S, Takahashi Y (2006) Relationship between bovine oocyte morphology and in vitro developmental potential. Zygote 14: 53-61

62. Cam H, Balciunaite E, Blais A, Spektor A, Scarpulla RC, Young R, Kluger Y, Dynlacht BD (2004) A common set of gene regulatory networks links metabolism and growth inhibition. Mol Cell 16: 399-411

63. Bratic I, Hench J, Henriksson J, Antebi A, Bürglin TR, Trifunovic A (2009) Mitochondrial DNA level, but not active replicase, is essential for Caenorhabditis elegans development. Nucleic Acids Res 37: 181728

64. Opiela J, Lipiński D, Słomski R, Katska-Ksiazkiewicz L (2010) Transcript expression of mitochondria related genes is correlated with bovine oocyte selection by BCB test. Anim Reprod Sci 118: 188-93

65. Van Blerkom J, Davis P (2007) Mitochondrial signaling and fertilization. Mol Hum Reprod 13: 759-70

66. Duran HE, Simsek-Duran F, Oehninger SC, Jones HW, Castora FJ (2011) The association of reproductive senescence with mitochondrial quantity, function, and DNA integrity in human oocytes at different stages of maturation. Fertil Steril 96: 384-8

67. Santos TA, El Shourbagy S, St John JC (2006) Mitochondrial content reflects oocyte variability and fertilization outcome. Fertil Steril 85: 584-91

68. Luo S-M, Ge Z-J, Wang Z-W, Jiang Z-Z, Wang Z-B, Ouyang Y-C, Hou Y, Schatten H, Sun Q-Y (2013) Unique insights into maternal mitochondrial inheritance in mice. Proc Natl Acad Sci U S A 110: 13038-43

69. St.John JC, Facucho-Oliveira J, Jiang Y, Kelly R, Salah R, StJohn JC, Facucho-Oliveira J, Jiang Y, Kelly R, Salah R, St.John JC, Facucho-Oliveira J, Jiang Y, Kelly R, Salah R, StJohn JC, Facucho-Oliveira J, Jiang Y, Kelly R, et al. (2010) Mitochondrial DNA transmission, replication and inheritance: A journey from the gamete through the embryo and into offspring and embryonic stem cells. Hum Reprod Update 16: 488-509

70. Mahrous E, Yang Q, Clarke HJ (2012) Regulation of mitochondrial DNA accumulation during oocyte growth and meiotic maturation in the mouse. Reproduction 144: 177-185

71. Moskalev AA, Shaposhnikov MV, Plyusnina EN, Zhavoronkov A, Budovsky A, Yanai H, Fraifeld VE (2013) The role of DNA damage and repair in aging through the prism of Koch-like criteria. Ageing Res Rev 12: 661-684

72. Jacobs L, Gerards M, Chinnery P, Dumoulin J, de Coo I, Geraedts J, Smeets H (2007) mtDNA point mutations are present at various levels of heteroplasmy in human oocytes. Mol Hum Reprod 13: 149-54

73. Agarwal A, Gupta S, Sharma RK (2005) Role of oxidative stress in female reproduction. Reprod Biol Endocrinol 3: 28

74. Zeviani M, Di Donato S (2004) Mitochondrial disorders. Brain 127: 2153-2172

75. Ng YS, Turnbull DM (2016) Mitochondrial disease: genetics and management. J Neurol 263: 179-191

76. Schlieben LD, Prokisch H (2020) The Dimensions of Primary Mitochondrial Disorders. Front Cell Dev Biol 8: 1441

77. Liufu T, Wang Z (2021) Treatment for mitochondrial diseases. Rev Neurosci 32: 35-47

78. Dalton CM, Carroll J (2013) Biased inheritance of mitochondria during asymmetric cell division in the mouse oocyte. J Cell Sci 126: 2955-2964

79. Wai T, Ao A, Zhang X, Cyr D, Dufort D, Shoubridge EA (2010) The role of mitochondrial DNA copy number in mammalian fertility. Biol Reprod 83: 52-62

80. Motta PM, Nottola SA, Makabe S, Heyn R (2000) Mitochondrial morphology in human fetal and adult female germ cells. Hum Reprod 15 Suppl 2: 129-47

81. Dvoŕak M, Tesarík J, Pilka L, Trávník P (1982) Fine structure of human two-cell ova fertilized and cleaved in vitro. Fertil Steril 37: 661-7

82. Allen JF, De Paula WBM (2013) Mitochondrial genome function and maternal inheritance. Biochem Soc Trans 41: 1298-1304

83. De Paula WBM, Agip A-NNA, Missirlis F, Ashworth R, Vizcay-Barrena G, Lucas CH, Allen JF (2013) Female and male gamete mitochondria are distinct and complementary in transcription, structure, and genome function. Genome Biol Evol 5: 1969-1977

84. Bentov Y, Yavorska T, Esfandiari N, Jurisicova A, Casper RF (2011) The contribution of mitochondrial function to reproductive aging. J Assist Reprod Genet 28: 773-83

85. Zhao RZ, Jiang S, Zhang L, Yu Z Bin (2019) Mitochondrial electron transport chain, ROS generation and uncoupling (Review). Int J Mol Med 44: 3-15

86. De Paula WBM, Lucas CH, Agip A-NA, Vizcay-Barrena G, Allen JF (2013) Energy, ageing, fidelity and sex: oocyte mitochondrial DNA as a protected genetic template. Philos Trans R Soc Lond B Biol Sci 368: 20120263

87. Tilly JL, Sinclair DA (2013) Germline energetics, aging, and female infertility. Cell Metab 17: 838-850

88. Hajkova P (2011) Epigenetic reprogramming in the germline: Towards the ground state of the epigenome. Philos Trans R Soc B Biol Sci 366: 2266-2273 
89. Peixoto P, Cartron PF, Serandour AA, Hervouet E (2020) From 1957 to nowadays: A brief history of epigenetics. Int J Mol Sci 21: 1-18

90. Messerschmidt DM, Knowles BB, Solter D (2014) DNA methylation dynamics during epigenetic reprogramming in the germline and preimplantation embryos. Genes Dev 28: 812-828

91. Zeng Y, Chen T (2019) DNA methylation reprogramming during mammalian development. Genes (Basel) 10: 257

92. Kota SK, Feil R (2010) Epigenetic Transitions in Germ Cell Development and Meiosis. Dev Cell 19: 675-686

93. Hiura H, Obata Y, Komiyama J, Shirai M, Kono T (2006) Oocyte growth-dependent progression of maternal imprinting in mice. Genes to Cells 11: 353-361

94. Obata Y, Kono T (2002) Maternal primary imprinting is established at a specific time for each gene throughout oocyte growth. J Biol Chem 277: 5285-5289

95. Strahl BD, Allis CD (2000) The language of covalent histone modifications. Nature 403: 41-45

96. Hoffmann S, Tomasik G, Polanski Z (2012) DNA methylation, histone modifications and behaviour of AKAP95 during mouse oocyte growth and upon nuclear transfer of foreign chromatin into fully grown prophase oocytes. Folia Biol (Czech Republic) 60: 163-170

97. Kageyama SI, Liu H, Kaneko N, Ooga M, Nagata M, Aoki F (2007) Alterations in epigenetic modifications during oocyte growth in mice. Reproduction 133: 85-94
98. Stewart KR, Veselovska L, Kim J, Huang J, Saadeh H, Tomizawa SI, Smallwood SA, Chen T, Kelsey G (2015) Dynamic changes in histone modifications precede de novo DNA methylation in oocytes. Genes Dev 29: 2449-2462

99. Bao S, Obata Y, Ono Y, Futatsumata N, Niimura S, Kono T (2002) Nuclear competence for maturation and pronuclear formation in mouse oocytes. Hum Reprod 17: 1311-1316

100. De La Fuente R, Eppig JJ (2001) Transcriptional activity of the mouse oocyte genome: companion granulosa cells modulate transcription and chromatin remodeling. Dev Biol 229: 224-36

101. Gasior L, Daszkiewicz R (2014) Przydatność oceny konfiguracji chromatyny oocytów ssaczych, jako markera kompetencji mejotycznych i rozwojowych. Postępy Biol Komórki 41: 637-649

102. Svoboda P (2018) Mammalian zygotic genome activation. Semin Cell Dev Biol 84: 118-126

103. Wu J, Xu J, Liu B, Yao G, Wang P, Lin Z, Huang B, Wang X, Li T, Shi S, Zhang N, Duan F, Ming J, Zhang X, Niu W, Song W, Jin H, Guo Y, Dai S, et al. (2018) Chromatin analysis in human early development reveals epigenetic transition during ZGA. Nature 557: 256-260

104. Jukam D, Shariati SAM, Skotheim JM (2017) Zygotic Genome Activation in Vertebrates. Dev Cell 42: 316-332 


\section{Cellular mechanisms ensuring the mammalian female germ cells quality}

Zbigniew Polański ${ }^{1 \otimes}$ and Łukasz Gąsior ${ }^{2}$

${ }^{1}$ Laboratory of Genetics and Evolution, Institute of Zoology and Biomedical Research, Jagiellonian University, Kraków

${ }^{2}$ Department of Neurobiology, Maj Institute of Pharmacology Polish Academy of Sciences, Kraków

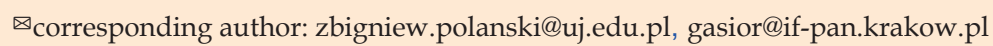

Keywords: oocyte, maternal information, chromosome segregation, DNA quality, mitochondria, chromatin reprogramming

\section{SUMMARY}

Gametes are extremely differentiated cells participating in the fertilization to give the beginning of a new life. Except enabling fertilization, however, the fully functional gamete, should also guarantee full and undisturbed development of the whole individual. The aim of this article is to approximate the mechanisms which occur during mammalian oogenesis which are crucial for ensuring the proper course of development as well as the quality of the genetic material transmitted to the progeny.

\section{informacja mateczna}

\section{mechanizmy utrzymujące integralność genomu}

\section{jakość mitochondriów \\ i mt DNA}

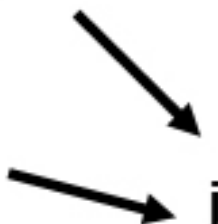

jakość oocytu

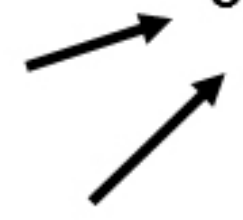

epigenetyczne

reprogramowanie

chromatyny 